\title{
MERCHANTS AND MINERS: ECONOMY AND CULTURE IN 17TH CENTURY MASSACHUSETTS AND POTOSI
}

\author{
POR \\ MARGARET E. NEWELL \\ Ohio State University
}

A critical reading of comparative studies of British and Spanish America reveals that historians tend to frame their analysis around dichotomies: conquest versus commerce, private control versus a centralized state, innovation versus atavism, and so on (1). The considerable environmental, demographic, economic, and cultural differences that distinguish the two Americas provide ample evidence for interpretations stressing contrasts. Yet this emphasis is also due in part to other factors: the differing research agendas of Latin American and United States historians, which make thematic comparisons difficult; and more importantly, the way in which historians approach the comparison. Organizing a comparative study around a single theme -in this case economic culture- offers a means to focus on similarities while acknowledging each society's distinctiveness.

My work to date has centered on colonial and Revolutionary New England (2). Examining the colonists' economic attitudes in the context of their activities, I argue that culture in New England -including Puritanism and the values which framed commercefostered economic development. This paper attempts to place

(1) See, for example, the chapters on elites and imperial governments in J. H. Elliott's forthcoming study. Some recent exceptions include works on the Atlantic economy, such as Peggy Liss' Atlantic Empires (Baltimore, 1983), and Liss' edited collection of essays, with Franklin KNIGHT, Atlantic Port Cities (Knoxville, 1991). But even Liss tends to focus en contrasts rather than comparisons, stressing the limits of 18th century Spains commitment to comercio libre, and England's role in the vanguard of change.

(2) M. E. NEwELL, Economic Ideology, Culture and Development in New England 1620-1800, Ph. D. Dissertation, Univ of Virginia, 1991. 
these arguments concerning the unique elements of 17 th century New England's "culture of development" in a comparative perspective. By comparing European backgrounds to colonization, the interplay of economic attitudes and religion, entrepreneurialism, business practices, and the role of the state in early Massachusetts and Potosi, the largest mining center of colonial South America (and literally a city on a hill), I hope to establish what, if anything, was truly unique about Massachusetts Bay's economic culture, and what merely reflected a general colonial context. In turn, by applying categories and interpretations from the New England context to existing literature concerning Potosí and the career of its leading 17th century entrepreneur, Antonio López de Quiroga, this essay seeks to reframe the comparative debate by identifying similarities as well as contrasts. Despite clear differences in their respective labor markets and resources, native populations, and the timing and control of the process of settlement, the mining and merchant elites of Boston and Potosi shared key cultural characteristics that facilitated entrepreneurial behavior and economic development. Potosinos' propensity for economic enterprise indicates that Massachusetts Bay's Puritan "culture of development" had a Latin American analog-a "Catholic capitalist ethic» (3). An examination of local histories, biographies, and secondary works suggests that distinct conceptions of the role of the state constitute the critical difference between economic thought and practice in the two societies.

Examining the European context for colonization represents the starting point for any analysis of British and Latin American economic culture. English commercial ties and political economic ideas clearly shaped the contours of economic culture in early Massachusetts. The merchants, professionals, and gentry landowners who participated in the "Great Migration" of the 1630s represented the vanguard of economic change in the mother country at a time when England, along with the Netherlands, was becoming the avant-garde commercial nation of earlymodern Europe. The original chartered colonies were themselves joint-stock companies, one of the newest methods of capitalization and incorporation available. Magistrates and ministers engaged in the formation of government in Massachusetts drew on the English Commonwealth tradition of active government encouragement of diverse economic projects, as well as from contempo-

(3) The term is Peter Bakewell's. See his Silver and Entrepreneurship, New Mexico, 1987, pág. 176. 
rary balance of trade theories of political economy that stressed diversification and import substitution. But John Winthrop, John Cotton, and other Massachusetts leaders demonstrated a pragmatic willingness to modify or abandon imported economic ideas and practices - particularly English regulatory policy- in the light of New World conditions.

If England occupies the vanguard of economic change in histories of early modern Europe, however, many accounts place 15 th and 16th century Spain in the rearguard of capitalist transformation. While acknowledging the innovations of Spanish stateformation and administration, these works stress the atavistic nature of the conquistadores, socio-economic goals and mentality (4). Yet James Lockhart, William and Carla Phillips, and other historians of the age of Spanish colonial expansion contend that, like England, imperial Spain provided a crucial ideological, conceptual and material context for the economic exploitation of the New World. By 1500 Spain boasted an experienced mercantile elite, a body of commercial law, ports capable of handling longdistance trade, links to international banking and credit communities, a tradition of gentry involvement in industry and commercial agriculture-all of which shapped the goals and expectations of participants in colonial ventures (5). Just as in New England, considerable occupational diversity and an ethic of "generalized commercial capitalism" characterized the first settlers in South America (6).

The output and organization of the Peruvian silver mining industry indicate that Potosi's mining and mercantile elite applied these lessons well, mirroring their counterparts to the North in attitudes towards work, risk, exchange, reinvestment, and the rational pursuit of diverse economic enterprises. Despite its forbidding climate and geographic and cultural isolation, the promise of fabulous wealth and the exigencies of the forced labor system,

(4) Several works describe the conquistadores as millenarian, anticommercial, obsessed with titles, and essentially military in character; or they regard the conquest period as essentially distinct from what followed. See, for example, James LanG, Conquest and Commerce: Spain and England in the Americas, New York, 1975: Tzvetan Todorov, The Conquest of America, New York, 1985, J. H. ElliotT, The Old World and the New, 1492-1650. Cambridge, 1970.

(5) James LockHART, "Trunk Lines and Feeder Lines: The Spanish Reaction to American Resources", and William and Carla PHILIPS, "Spain in the Fifteenth Century". In Ken ANDRIEN and Rolena ADORNO, eds., Transatlantic Encounters: Europeans and Andeans in the Sixteenth Century. Berkeley, 1991, págs. 30-34, 90$1,99$.

(6) James Lockhart, Spanish Peru, 1532-1560: A Colonial Society Wisconsin, 1968, págs. 221-226. 
or mita, had attracted a heterogeneous population of over 120.000 Europeans, Africans and Amerindians to Potosí by 1620 - "only the determined, the ambitious, the avaricious, the very needy, or ... the compelled completed the journey," notes Peter Bakewell. Servicing this population and supplying an ever more technologically advanced mining industry in turn stimulated inland and international trade, as well as local processing and agricultural production. Potosi's exploitative, competitive, boomtown atmosphere, as well as «the wealth of its residents and excess of worldly goods", became bywords among contemporaries: "no sooner have figs and grapes ripened than they appear in the plaza - before the viceroy has them on his table in Lima" (7).

In addition to the European background, other cultural factors such as religion and communal values shaped the contours of economic activity in both New England and Potosí. For example, the imperatives of the Puritan work ethic proved critical to development in Massachusetts Bay. Ever since Max Weber identified Calvinism's role in promoting the disciplined habits characteristic of capitalism, historians of New England have focused on the economic significance of Puritanisms emphasis on work, productivity, industry, frugality, rectitude and stewardship. These values composed an ethical system that encouraged the intensive use of resources, investment, and the physical expansion of New England. "God gave [humankind] a general Commission" explained Gov. John Winthrop: «increase and multiply and replenish the earth and subdue it ... that men may enjoye the fruit of the earth, and God may have his due glory from the Creature, which is imperfect while it lyes waste" (8).

The New England colonists applied these ideas pragmatically and flexibly. The inhabitants' commitment to church, community and commonweal influenced the course of economic change in New England, occasionally conflicting with developmental imperatives; but the power of these ideas and institutions also provided a moral and social context for economic change that made it easier for New Englanders to participate in the new commercial order (9). Given New England's lack of marketable commodities and desperate need for foreign exchange, the colonists had to

(7) Bartolomé ARzáns de Orsúa y Vela, Historia de La Villa Imperial de Potosi, Lewis Hanke and Gunnar, Mendoza, eds. Providence, 1965, I: 184x; "Historia de Huérfano (sic) por Andrés de León...", quoted in BAKEWEL.L [3], pág. 24.

(8) Allyn, F. ForBes, ed., Winthrop Papers Boston, 1957, 5 vols., II: 123-4.

(9) The "New England Town" is a perfect illustration of this phenomenon. Although after the mid-1650s, speculative concerns more than religion inspired the founding of new towns and the physical expansion of the New England governments, the fact that economic growth often took the form of town- 
"learn commerce or perish". A commitment to hard work did not preclude extensive use of credit and indebtedness, nor the creation of an economy based on serving as middleman/carrier for other colonial producers. An excess of frugality and limits on consumption would have resulted in economic stagnation and precluded incentives for market participation. Puritan leaders deemed sumptuary legislation a failure by 1638 , tacitly acknowledging the link between material incentives - the "competencies" and "decencies" of life- and productivity (10). The General Court's concerns about consumption stemmed more from anxiety over the levelling of social distinctions than any religious imperatives. Far from institutionalizing a "moral economy», Massachusetts abandoned all attempts to replicate English-style price and wage controls within two decades of settlement (11). In 1643, the General Court loosened restrictions on usury and lifted the $8 \%$ ceiling on interest rates for bills of exchange in order to ease credit and facilitate international trade.

Thus religion in Massachusetts fostered and gave meaning to economic activity in a variety of ways, creating a society, in Edward Winslow's words, "where religion and profit jump[ed] together" (12). Rectitude proved a business asset in an international trade network, noted merchant John Hull, where a good

founding allowed the colonists to pursue development within a stable, communal framework. New Englands town-based polities not only served as effective units of political administration, market centers, and developmental projects; they also provided cultural continuity through institutions like churches, schools and town meetings. The importance of the town as a developmental unit in New England offers yet another fertile field for comparison with Latin America.

(10) When the General Court attempted to control the influx of consumer goods by limiting access to incoming commercial vessels to a few licensees in 1632, settlers rowed directly out to the ships in harbor in order to purchase their wares, The General Court also gave up on its back-up plan - an anti-consumption compaign of moral suasion- upon discovering that divers of the Elders wives, etc. were in some measure partners of the general disorder" Similarly, a scarce labor market and the availability of land undermined all attempts to fix wages or to reinstitute anything approaching England's Statute of Artificers. William WEEDEN, Economic and Social History of New England, 1620-1789, 2 vols. Boston, 1890, I: 125, J. Franklin JAMESON, ed., [Edward Johnson's Wonder-Working Providence, 1628-1651 New York, 1910, págs. 209-210, James Kendall HoSMER, ed., Winthrop's Journali: "History of New England", 2 vols. New York, 1908, I: 279.

(11) Gov. Winthrop explained that regulation had to be abandoned "because a certain rule would not be found out for an equal rate between buyer and seller, though much labor had been bestowed in it, and divers laws had been made, which, upon experience, were repealed, as being neither safe nor equal" Winthrop's Journal, I, 316.

(12) Edward Winstow, Good News from New England: or a true Relation of things remarkable at the Plantation of Plymouth in New England, London, 1624. 
reputation assured access to credit (13). Although the Bay colonists' communitarian religious values occasionally served as a check on economic individualism, entrepreneurs and policy makers appealed to "the common good" to justify a variety of public and private economic ventures such as mills, ironworks, and even distilleries. For example, during a push for economic diversification in the 1640s, ministers and magistrates like John Winthrop Jr. and Hugh Peter advocated, that the colony adopt realistic levels of religious and social accommodation in order to attract skilled, but unorthodox, laborers from England for major projects like the Saugus ironworks.

Potosinos faced a similar economic landscape -lack of capital, the high cost of labor and supplies, lack of managerial skills, and a dependence on imports - in the 1600s. After peaking in the 1590 s, silver production in Potosí steadily declined and the costs of extraction and labor rose, requiring increased investment and rewarding economies of scale. Yet market instability and bankruptcies ironically eased entry into mining, commerce and credit for enterprising newcomers such Antonio López de Quiroga. The strategies that López de Quiroga and other successful miners adopted in the face of these conditions suggest the presence of a "Catholic capitalist ethic", to borrow Bakewell's term, among Potosinos. The magnitude of López de Quiroga's myriad enterprises distinguished him among Potosi's commercial elite, but the region's encomenderos, miners and merchants evinced similar entrepreneurial attitudes. Potosi's economic and political elites ignored customary prohibitions on participation in trade, engaging directly in crucial management roles (14). The American context permitted a degree of mobility and social levelling that blurred strict occupational and class distinctions, providing incentives for ambitious commoners and petty gentry. Potosinos boasted an abundance of the spirit of emulation and risk in the pursuit of profit rather than titles, noted the licenciado of La Plata in a 1682 letter to the King: miners sought "the vanity of having distributed [silver], and the desire to have yet more to distribute, by overturning and disembowelling mountains... it is a matter of

(13) John Hull to Daniel Allin, Jan. 10, 1672/3; Hull to James Stevens, Nov. 21, 1672; both in the John Hull Papers, American Antiquariam Society.

(14) BAKEWELl [3] pág. 176. The Spanish crown found it necessary in 1682 to issue a decree instructing elites that "to maintain ... manufactures ... is not contrary to the quality inmmunities and prerogatives of nobility ... so long as those who maintain manufactures do not labor with their own persons but through their servants and officials". 
special providence for the maintenance of so risky a profession [as mining] that there should exist... these spirits" (15).

The providential cast of the above quote is instructive; rather than limiting speculative activity, religion provided a context for entrepreneurialism in Potosí as well as New England. Several contemporaries, including López de Quiroga and Bartolome Arzáns de Orsúa y Vela, Potosi's chief chronicler, described the social value of work in ways that echoed New Englanders' notion of the calling, and articulated such so-called "Protestant" concepts as stewardship regarding their personal and communal wealth - "Providential riches», in Arzáns' words. In petitions for licenses, offices and other concessions from the Crown, López de Quiroga placed his personal wealth in the context of his industriousness, improvements and contributions to the common good; he aimed not "to store up wealth", he insisted, "but to serve his Majesty in the increase of his royal quintos». Rather than living off rents, his chaplain contended, López continued to work, risk and invest and to employ fellow Potosinos, "moved by the generous and liberal spirit that God gave him" - all the while enriching himself further (16). Like John Hull, López also expressed an awareness of the economic utility of virtues such as uprightness and fair dealing (17). Catholicism placed no appreciable restraints on Potosinos' economic behavior. Just as in New England, authorities relaxed restrictions on immigration in order to attract nonSpanish, even non-Catholic, settlers with technical or managerial expertise (18). Potosi's aviadores, or merchant-creditors, largely ignored prohibitions on usury and masked interest payments in a variety of ways. Contemporaries marvelled at López de Quiroga's propensity for reinvesting his profits; Arzáns noted disapprovingly that the miners devoted only a fraction of their wealth to display and almsgiving.

Responses and adaptations to the New World environment represented another key aspect of economic culture in both regions. In New England, poor soil and lack of a staple crop to exchange for consumer goods, coupled with a desire to replicate

(15) Licenciado don Bartolomé González Poveda to the King, La Plata, Aug. 20, 1692, quoted in BAKEWEL [3] págs. 162-3.

(16) López de Quiroga, quoted in BaKewel [3] pág. 138, Arzáns, I: 117, Juan Araujo, quoted in Bakewell, pág. 138.

(17) BAKEWELL [3], pág. 51.

(18) Peter BAKEWELL, Miners of the Red Mountain: Indian Labor in Potosi, 1545-1650. Albuquerque, 1984; see also the Hanke and Mendoza Introduction to Arzáns. Historia [7]. 
an "English" standard of living, forced the inhabitants to adopt a variety of developmental strategies during the colonial period, resulting in a relatively diverse economy based on complex multilateral trade and credit networks, carrying, processing, some manufacturing, and financial services. James McCusker and Russell Menard regard New England as an archetypal example of a developmental economy largely because of the region's success in establishing these backward and forward "linkages" - producing something of an economic chain reaction (19). English observer Edmund Randolph described the dynamic character of the Massachusetts economy in the 1670s: "the merchants... keep their ships in constant employment, which makes them seek all ports and places to force a trade, whereby they abound with all sorts of commodities" (20). Unlike tobacco, the types of goods New Englanders produced and shipped stimulated a range of related productive enterprises and services. This commerce also required that merchants develop the means of marketing and distributing the consumer goods they secured in return. Finally, dependence on English imports led New England merchants and policymakers to support the manufacturing of local substitutes. Thus whereas the linkage benefits from Virginia's tobacco production largely accrued to the mother country, New England quickly developed its own infrastructure of mills, ports, distilleries, ironworks, shipyards, general stores, and credit facilities. For example, to ensure steady supplies and increase profits, merchants like John Hull and Thomas Fitch gradually engaged in production and marketing of the shingles, flour, turpentine, rum and other commodities they exported, constructing mills, hiring managers, initiating partnerships, and generally rationalizing these enterprises. Magistrates used their connections in government to secure access to land, timber and other resources.

Yet in the context of early Latin American history, historians tend to characterize similar behavior quite differently. James Lang argues that encomenderos and miners merely conquered and exploited existing productive systems without contributing much in the way of organization, development or creative adaptation (21). Others ascribe the desire of Spaniards and creoles to establish estates, seek titles and other offices, and gain recognition

(19) John McCusker and Russell, MEnard, The Economy of British America, 1607-1789, Chapel Hill, 1985, págs. 23-6.

(20) Quoted in Curtis NetTEls, The Money Supply of the American Colonies Before 1720 New York, 1964, pág. 103.

(21) LANG, [4], pág. 18. My use of Lang here constitutes, in some ways, setting up a straw man. He subsequently acknowledges the enterprising character of creoles, technological and commercial activities in Peru's mining sector. 
for their family groups or lineage to atavistic impulses incompatible with entrepreneurialism. Yet Bakewell and Lockhart rightly point out that success in Peruvian mining by the 1600 s required levels of capitalization, exploration, technological innovation, and managerial expertise that far outstripped the capacity of Boston merchants (22). Refining mills, canals, dams and resevoirs crisscrossed the "rico Cerro", or chief mine; and even though Potosi produced a staple silver - feeding, transporting, and equipping thousands of Amerindian laborers and millions of tons of ore created its own set of «linkages».

In fact, business practices and credit arrangements in both societies mirrored one another - in part because Boston's merchants and Potosi's miners operated within a shared New World context. Like Hull and Fitch, López de Quiroga attempted to minimize his risks and reduce expenses by diversifying into agriculture, leather and wool production, stockraising, and other enterprises related to the production of his key commodity, silver. Miners and encomenderos also invested in import-substitution wherever possible, with such success that domestic wines, oils, and coarse woolens began seriously to undermine Spanish imports by the mid-17th century.

In this context, establishing an hacienda and investing in land, particularly near commercial centers like Potosí, formed part of an overall economic strategy rather than an attempt to distance one's self from commerce (23). Similarly, offices, honors and kin ties represented business assets, components of an individual's economic strategy. They provided access to lucrative trade contracts, mine licenses, land rights; and the extended family remained the main source of credit and managerial assistance for most early modern enterprise, in Massachusetts and England as well as Potosí. In the fluid social structure that characterized colonial societies, titles and offices offered added incentives for ambitious entrepreneurs, and signalled a commitment to the colonial, rather than the metropolitan, context.

Potosi's miners, encomenderos and peruleros, or merchantmiddlemen, also quickly established "forward» linkages in the marketing and distribution of foreign imports. In 1623 Seville's merchant community complained to the Count of Olivares that

(22) An attempt to stablish a large-scale ironworks in Saugus, Mass, in the 1640 s failed largely because of undercapitalization and managerial problems. See E. N. Harley, Ironworks on the Saugus, Norman, OK, 1957.

(23) Lockhart [3], págs. 97, 100. 
these "drones in the hive of Spanish commerce... assemble all the silver from Peru, silver which ought to be employed in purchasing from the fleet at Portobellon, bypassing official ports and licensees and purchasing directly in Spain or via the Manila trade (24). Chinese silks underpriced Spanish woolens in the Potosí market by the 1670 s.

The final component of Massachusetts Bay's culture of development - the translation of the economic attitudes outlined above into public policy - offers the greatest contrast with Potosí. Unlike Virginia, Barbados, and other English colonies, New England's very paucity of resources meant that the region attracted little regulatory interest from the crown (25). This left the inhabitants free to devise and implement their own explicitly prodevelopment public policy. In doing so, the Massachusetts General Court discarded English traditions of socio-economic regulation - guilds, price and wage controls, sumptuary laws- and constructed a state that intervened in the economy to aid private enterprise and to promote development. Beginning in the 1640s, both town and colonial government sponsored quality controls and inspection, which facilitated the export of New England goods; road-, bridge-, and inn-building, to ease access to internal markets; and a variety of bounties, tax abatements, land grants, monopolies and other incentives to promote desired trades and processing industries vital to Massachusetts' economy. The General Court also enacted protectionist legislation designed to foster diversification and nascent manufacturing - even at England's expense (26). The notion of commonwealth justified all of these actions, including private profit in the eyes of Boston's magistrates and ministers.

Although English regulation provided «a context for colonial merchants" and put a premium on connections with the mother country, the Navigation Acts of 1660-1696 had relatively little

(24) John LyNCH, Spain Under the Hapsburgs, London, 1976, II: 219.

(25) As late as 1654 Sir Francis Brewster referred to New England as "the most useless and unprofitable Plantation of this Nation"; Sir William Petty recommended that the region's industrious citizens be encouraged to remove to the Caribbean or Ireland. Sir Francis BREWSTER, Essays on Trade and Navigation, London, 1654/5; Charles M. ANDREwS, The Colonial Period of American History, New Haven, 1934-38, IV: págs. 338-9.

(26) Like their English counterparts, Boston's magistrates subscribed to the balance of trade theory of development, justifying their interventionist programs on the grounds of New England's trade deficit with the mother country: "So long as our ingate exceeds our outgate, the ballance must needs be made [up] within such as proportion as is with us [which cann leave us but litle mony]. Nathaniel Shurtleff, ed., The Records of the Massachussets Bay, III; pág. 92. 
impact on local policy in New England (27). An anonymous observer informed the Lords of Trade in 1682 that New Englanders "live altogether as if they denied [the king's] Authority, and imp[ose] Arbitrary Laws on all Trafiques hithen. New England largely benefitted from the elimination of the Dutch from British American trade, and the restrictions on exports of enumerated goods left most of the region's exports exempt. English authorities tolerated a high volume of smuggling and contraband, including Bostonians' illicit trade with the French, Dutch and Spanish Caribbean. Thus New England's participation in the English commercial empire cost little, and provided enormous benefits. A group of English merchants bitterly complained in 1676 that "New England is become the great mart and staple, by which means the navigation of [England] is greatly prejudiced (28).

In contrast, Potosi's inland merchants and miners, although posseessed of far greater natural advantages, faced a range of imperial restrictions and controls that hindered capital formation, discouraged innovation, enforced centralized monopolies, limited access to lucrative enterprises, and excluded Americans from most levels of commercial policymaking. Spain created a far more pervasive bureaucratic and economic administration in its colonial possessions within decades of settlement than England achieved in the entire colonial period. Whereas England concentrated on the indirect, mercantile benefits of colonization, the Spanish Crown extracted a far greater percentage of the Potosinos' available resources and capital. The quinto, (the king's onefifth share in silver production), the royal monopolies on the mercury essential to silver refining, sales taxes, import/export taxes, and licensing fees all diverted capital from local investment. Nor did the Hapsburgs ignore the mercantilist benefits of controlling colonial trade to the advantage of the mother country through the use of designated ports and licensed merchant monopolies. Even given the gap between the aspirations of the Hapsburg state and the realities of administration and enforcement, these regulations exercised an enormous affect on the colonial economy.

Colonial entrepreneurs succeeded in modifying this context in a variety of ways during the 17 th century. Venality in office

(27) The quote is from Bernard BAILYN, The New England Merchants in the Seventeenth Century, Boston, 1955, 1979, pág. 113.

(28) Calendat of State Papers, Colonial Series, America and West Indies, London, 1675-76. 
after 1630 allowed creoles access to key municipal offices in areas like Potosi. Once in power, creoles and even peninsulares with local contacts allied to block and alter objectionable crown policies, invoking the formula: "I obey but I do not comply" (29). As Ken Andrien contends, local officials ensured that a growing percentage of the funds collected through the quinto and other taxes remained in Peru as the century wore on, and applied the funds to defense, salaries, internal improvements, and other local project (30). Miners and merchants grew adept at manipulating institutions like the mita, which amounted to a state subsidy, for private profit and investment capital. For example, Jeffrey Cole notes that as many as one-fifth of mita Indians paid cash for exemption from the labor draft; miners pocketed the cash, and posted low silver output (and therefore lower quintos) for the year (31). Plummeting Spanish exports to America in the 17th century attest to the fact that Potosinos exchanged their silver for Asian and European goods obtained through illicit trade. Flourishing contraband trade routes linked Potosi with Buenos Aires and Brazil, bypassing official ports and suppliers.

But modifying crown directives did not constitute a developmental public policy. Spain, not Potosí, established the political and economic context for local entrepreneurs. Peru's creoles lacked legitimate political institutions analogous to the Massachusetts General Court; and therefore lacked the power to enact policy that reflected their particular, local economic interests. In addition, Potosinos needed the central state that Spain provided; the mining industry depended on subisidies such as the mita and a steady supply of mercury from government mines, as well as a judicial system capable of upholding contracts and protecting claims and property.

This comparison of economic attitudes in 17th century Boston and Potosi suggests the need to re-evaluate our conceptions concerning culture and development in Spanish America by assessing similarities as well as differences across regions and over time. Settlers in both regions shared a Old World economic background characterized by merchant capitalism; religious values that encouraged rather than impeded economic activity;

(29) Ken ANDrien, "Spaniards, Andcans, and the Early Colonial State in Peru" in Transatlantic Encounters, pág. 128.

(30) Ken ANDRIEN, Crisis and Decline: The Viceroyalty of Peru in the Seventeenth Century, Albuquerque, 1985, Ch. 2.

(31) See Jeffrey Cole, the Polosi Mita, 1573-1700: Compulsory Indian Labor in the Andes, Stanford, Calif, 1985. 
and attitudes towards work, risk and accumulation that indicated strong entrepreneurial tendencies. New England merchants and Peruvian miners evolved similar business strategies in response to New World conditions, and constructed diverse, integrated economies.

Comparison with early Massachusetts also points to the need to re-examine the role of the state and public policy in colonial Spanish America, since this topic offers the most salient contrasts with British America. The creoles' lack of political and economic autonomy left them without some of the resources and public policy tools that aided New England's development, with crucial consequences for the Peruvian economy during the 18 th century. New Englanders' control of the state and its developmental apparatus had equally crucial long-term implications not only for the economy, but also for political culture and the emergence of liberal ideology in the decades preceding independence. 